\title{
Krasnodar Agglomeration as a Project: Political and Administrative Development Resources
}

\author{
Alexey Kolba ${ }^{1, *}$ Maria Tereshina ${ }^{1, a}$ Laura Shpiro ${ }^{1, b}$ \\ ${ }^{1}$ Kuban State University, Krasnodar, Russia \\ ${ }^{a}$ E-mail: mwstepanova@mail.ru \\ bE-mail: laurok98@mail.ru \\ *Corresponding author.E-mail: alivka2000@mail.ru
}

\begin{abstract}
In the article, the authors study the possibility of applying a design approach to managing the development of an agglomeration. They identify the main structural elements of the agglomeration as an object of project management, as well as target principles and main management tasks. Using the example of Krasnodar agglomeration, the authors consider the priorities of agglomeration development in the context of the priorities of national and regional projects. The authors name the main characteristics of the project for the development of Krasnodar urban agglomeration.
\end{abstract}

Keywords: agglomeration, project management, development project, Krasnodar agglomeration, political and administrative development resources

\section{INTRODUCTION}

The formation of agglomerations is a historically inevitable process of the formation of highly concentrated urbanized forms of settlement. Urban agglomerations are rapidly developing all over the world and often consist of tens and hundreds of settlements, united by a common economic, transport, social and cultural space.

Today, the following main approaches to the study of urban agglomerations can be distinguished: economic [1] [2], geographical [3] [4] [5], social [6] [7], urban planning [6] [8] [9], environmental [10] and management [11]. At the same time, despite the differences determined by various research focus, all the above-mentioned approaches understand an agglomeration as a complex multi-compound system, the structure of which is determined depending on the nature of its constituent elements, the nature of the connections between them, the nature of the system itself (form of organization), as well as the type of nuclearity (single or multi-core).

The development of urban agglomerations is one of the strategic priorities of the spatial development of Russia. On the territory of the Russian Federation, there are about 40 such formations, classified as large and

*Fund: This work was supported by The Russian Foundation for Basic Research and the Administration of Krasnodar Krai № 19-411230022 "Political and administrative resources of public management of the social and economic development of the Krasnodar agglomeration". largest, with a total population of more than 73 million people [12]. Moreover, the process of their development took place in many respects spontaneously, proceeding from the natural needs of the socio-demographic, economic, political and managerial type. In recent years, it has become more manageable, primarily due to institutionalization that takes place in various forms. These include:

- laws and draft laws of the constituent entities of the Russian Federation in the field of managing the development of agglomerations;

- documents of strategic planning of the constituent entities of the Russian Federation, updating the agglomeration agenda

- concepts and strategies for the development of agglomerations;

- schemes of territorial planning of the constituent entities of the Russian Federation, including agglomeration discourse and schemes of territorial planning of agglomerations;

- intermunicipal agreements on cooperation within agglomerations;

- creation of management bodies for the development of agglomerations;

- development of industry documents on certain aspects of the development of agglomerations [13]. 
Recently, a Draft Federal Law "On urban agglomerations" was developed [14]. Thus, significant progress has been achieved both in the conceptualization of ideas about agglomerations, and in the practical activities of political and administrative structures for their development.

However, the project approach in this area is still rarely used [15]. The examples of its use for the purposeful development of goals, objectives, stages of development, determination of the necessary resources are unknown to us. In this regard, the task of studying the possibilities of this approach in relation to agglomeration development, the main aspects of the effectiveness of its application is urgent.

\section{STRUCTURAL COMPONENTS OF AGGLOMERATION AS AN OBJECT OF PROJECT MANAGEMENT}

In modern political and administrative systems, project management plays one of the important roles. Its implementation laid the foundations for a new managerial ideology capable of changing the principles of not only managerial decision-making, but also the achievement of priority goals of social development, the nature and style of managerial activity. The theoretical origins of substantiating the applicability of project management in the implementation of public policy are laid in the concept of New Public Management by P. Aucoin and K. Hood [16]. The project-oriented approach in public administration is a management system in which the goals of the executive bodies of state power are achieved mainly through the implementation of projects and programs that have:
- ambitious goals and openness of content;

- complex nature and multilevel structure of target indicators;

- rigid legal framework for the implementation of activities;

- significant scale of public investment; significant number of participants and external stakeholders;

- focus on improving public goods and the quality of life of the population [17].

The implementation of the project approach in government bodies involves activities in two key areas: state design (selection of strategic goals and priorities, formation of a portfolio of national-scale projects, identification of resources for their implementation and consolidation in the national budget) and creation of a state project management mechanism (formation of institutional design project management in the system of public authorities at the national and regional levels, institutional consolidation and normative unification of the stages of project activities: preparation, implementation, completion, assessment).

The use of the project approach in the management of urban agglomerations makes it necessary to identify the main structural components of an agglomeration and target principles, based on which an appropriate choice of goals and objectives of the project is possible.

The main agglomeration subsystems, their constituent components and the target principles of agglomeration management are shown in the "Table I".

TABLE I. THE STRUCTURE OF THE AGGLOMERATION AS AN OBJECT OF PROJECT MANAGEMENT (COMPILED BY THE AUTHORS)

\begin{tabular}{|c|c|c|}
\hline & Components & Target management principles \\
\hline \multirow[t]{2}{*}{ Economic subsystem } & Resources & resource interaction \\
\hline & $\begin{array}{l}\text { Natural } \\
\text { Capital } \\
\text { Labor } \\
\text { Informational }\end{array}$ & $\begin{array}{l}\text { Technological interaction } \\
\text { Territorial proximity } \\
\text { Transport organization } \\
\text { Equal accessibility of benefits }\end{array}$ \\
\hline \multirow[t]{2}{*}{ Ecological subsystem } & Natural landscape & $\begin{array}{l}\text { interaction of natural and anthropogenic } \\
\text { capital }\end{array}$ \\
\hline & $\begin{array}{l}\text { Relief } \\
\text { Water frame } \\
\text { Conservation areas } \\
\text { Flora and fauna } \\
\text { Climate }\end{array}$ & $\begin{array}{l}\text { Ecosystem and aesthetic optimization, } \\
\text { sustainability and continuity of the natural } \\
\text { and ecological framework }\end{array}$ \\
\hline \multirow[t]{2}{*}{ Social subsystem } & Population needs & $\begin{array}{l}\text { Interaction in the system of meeting the } \\
\text { population needs }\end{array}$ \\
\hline & $\begin{array}{l}\text { Depending on the: } \\
\square \text { demographic characteristics } \\
\square \text { income level } \\
\square \text { educational level } \\
\square \text { areas of activity }\end{array}$ & $\begin{array}{l}\text { Ensuring that benefits and services are } \\
\text { equally accessible }\end{array}$ \\
\hline
\end{tabular}




\begin{tabular}{|c|c|c|}
\hline & Components & Target management principles \\
\hline \multirow[t]{2}{*}{ Geographic subsystem } & Territory functions & $\begin{array}{l}\begin{array}{l}\text { Functional complementarity of different } \\
\text { territorial zones }\end{array} \\
\end{array}$ \\
\hline & $\begin{array}{l}\text { production } \\
\text { transport } \\
\text { administrative } \\
\text { economic } \\
\text { research } \\
\text { agricultural } \\
\text { recreational }\end{array}$ & $\begin{array}{l}\text { Providing access to other functions from a } \\
\text { distance } \\
\text { Grouping related functions in the territory }\end{array}$ \\
\hline \multirow[t]{2}{*}{ Management subsystem } & Administrative elements & Interaction in solving joint problems \\
\hline & $\begin{array}{l}\text { urban or rural settlements, } \\
\text { municipal areas, urban districts, } \\
\text { etc. }\end{array}$ & Mutually beneficial use of the resources \\
\hline
\end{tabular}

Considering agglomerations as systemic spatial and socio-economic formations, one cannot but ask the question of the starting conditions that determine the formation of elements necessary for the sustainable development of the agglomeration, as well as their effective integration. This question is especially important in the context of our study, since its object is Krasnodar urban agglomeration, which is at the initial stage of formation. I.V. Volchkova [18] introduces the concept of an emerging urban agglomeration, which is understood as "a specific socio-territorial object - a potential system for integrating internal and external socio-economic and infrastructural interactions aimed at achieving effective forms of managing regional processes." The same author identifies two groups of factors that determine, on the one hand, the starting conditions, which can serve as indicators of the "suitability" of a territory for the emergence of an agglomeration, and, on the other hand, characterize the formation processes themselves. So, according to I.V. Volchkova, the first group includes the socio-economic connectedness of the territory, a variety of economic activities and professional structure, transport accessibility and availability of communication services, a developed communications network and a developed transport infrastructure that ensure the availability and variety of different services.

The second group of factors includes political and administrative resources for development: formation of a regulatory framework, as well as strategies and programs for socio-economic development, implementation of effective standards and management models, the development of uniform living standards of the population and mechanisms of inter-municipal cooperation, creation of a single market for labor, land, capital, real estate. Thus, the author emphasizes that an agglomeration is formed naturally, but its further development requires serious management influences, without which, according to the figurative expression of the geographer M. Rouge, agglomerations "spread like an oily stain" and turn into a "cancerous form of urban formations" [19].
The tasks of managing the development of an agglomeration as a project in the most general form can be defined as the following:

- diversification of the economy based on the development of the system of labor division. The core of the agglomeration attracts all the main (production, administrative, cultural, etc.) functions. Such a load objectively leads to an excessive burden of the environmental, transport, and infrastructure spheres, a decrease in the quality of life of the population and the impoverishment of the periphery. In the case of controllability of the agglomeration process due to the redistribution of functions between the core and adjacent territories, the city-center is freed from non-core functions, de-concentration and more balanced socio-economic development occur. At the same time, resources for the development of a specific function are not "spread" throughout the entire territory, but are purposefully concentrated in a specialized area.

- optimization of the transport scheme. Ideally, the transport accessibility of the city center for all settlements should be provided within an hour.

- optimization of integrated land use development. Since one of the main reasons for the formation of agglomerations is precisely the limited land resources in cities, while, especially in the suburbs, the "spontaneous" allocation and development of plots leads to housing unsecured with social infrastructure, unreasonable transfer of land from one category to another, which is dictated primarily commercial interests, reduction of agricultural land, recreational and green areas, then project efforts should be aimed at creating a coordinated system of territorial planning and land use, taking into account their urban planning value.

- formation of the natural and ecological framework of the territory. The already mentioned uncontrolled building leads to a 
reduction in the area of green spaces, destroys the natural landscape. The most important project task is the preservation and expansion of natural zones, "green" corridors, "ecological tissue" of the territory.

- implementation of large infrastructure projects. The construction of logistics hubs, airports, energy facilities and the joint use of such infrastructure facilities, firstly, more efficiently due to economies of scale of production, and secondly, it becomes possible to attract additional funding through federal infrastructure investments.

- optimization and comprehensive development of communal infrastructure, in particular, waste disposal systems, taking into account the selection of the most optimal landfill locations, construction of modern waste processing plants, etc. Currently, none of the municipalities can independently solve the problem of effective waste processing. In this regard, a significant number of conflicts arise over the placement of landfills. The design of the general engineering infrastructure and its operation can reduce the cost of its maintenance.

- balanced development of educational, shopping, entertainment and social infrastructure. Designing transport-accessible specialized complexes (shopping and entertainment, educational, etc.) throughout the agglomeration, not only in its center, will avoid transport problems, the proliferation of markets and retail space in the historical central districts of the city, and bring the level of development of the surrounding settlements to urban.

- smoothing the disproportion in the development of the agglomeration territory between the urban center and the suburbs and strengthening agglomeration ties through the creation of new industries in new territories.

\section{DEVELOPMENT OF KRASNODAR AGGLOMERATION IN THE CONTEXT OF NATIONAL AND REGIONAL PROJECTS}

The development of agglomerations in modern Russia occurs during the implementation of national and regional projects and is directly related to a number of them. At the federal level, we distinguish the following projects:

- 1 . Within the framework of the national project "Housing and Urban Environment" is the federal project "Formation of a Comfortable Urban Environment", according to which by 2024 an increase in the quality of the urban environment by $30 \%$ should be ensured.

- 2. Within the framework of the national project "Ecology" is the federal project "Clean Country", according to which, by 2024, almost 200 unauthorized landfills within the city limits will cease to exist.

- 3. Within the framework of the national project "Digital Economy" is the federal project "Information Infrastructure", according to which $5 \mathrm{G}$ networks will be deployed in cities with a population of one million [20].

- 4. Within the framework of the national project "Safe and high-quality highways" is the federal project "Road network", according to which in 104 urban agglomerations the share of roads meeting quality standards should double (from 42 to $85 \%$ ).

It should be noted that for the first time the issue of delimitation of the boundaries of Krasnodar agglomeration was raised as part of the development of the draft Strategy for the socio-economic development of Krasnodar Krai for the period up to 2030. At the same time, it was assumed that the formation of Krasnodar agglomeration would become a joint project of Krasnodar Krai and the Republic of Adygea, and territorially, the project would cover the Dinskaya and Seversky regions, Goryachiy Klyuch, as well as the Takhtamukaysky and Teuchezhsky regions of the Republic of Adygea and the city of Adygea. This format is extremely difficult to design, which is explained by the inclusion of two regions in the agglomeration and the absence of such precedents in domestic practice.

Regional projects implemented as part of national ones are also relevant for Krasnodar urban agglomeration. To a large extent, they directly duplicate each other, but at the level of a constituent entity of the federation there is also a link to regional development programs implemented in the corresponding directions.

The most ambitious project currently being implemented is the construction of a backup for the Yablonovsky bridge across the Kuban River, connecting Krasnodar Krai and the Republic of Adygea. This project makes it possible to form a new vision of the development of Krasnodar agglomeration within the framework of the design of interregional cooperation.

Thus, the formation and further growth of the agglomeration at this stage are inscribed in the context of the project activities of federal and regional authorities. Municipalities are also subjects of the implementation of these projects on a local scale. 
We believe that the relevance of the project approach to the management of urban agglomerations is associated with the possibility of implementing unique events and building up resources for the formation of innovative technologies for managerial influences on the related subsystems of the urban agglomeration and the processes occurring in them. At the same time, the implementation of the design approach at the level of individual municipalities within the agglomeration should be integrated with the design of the development of the agglomeration as a territorial entity of a higher level [21]. Inter-municipal projects within the framework of urban agglomerations can be associated with cooperation in solving problems of improving the quality and volume of provided social services, which require significant financial and material resources, the construction and maintenance of infrastructure facilities, solving the problem of solid municipal waste, etc.

\section{KEY CHARACTERISTICS OF THE DEVELOPMENT PROJECT OF KRASNODAR AGGLOMERATION}

Analysis of the experience of project management in the field of spatial development allows us to identify several necessary components of its structure. These include the customer of the project, his manager, target group, goals and stages of development.

Since the project activity in this case goes beyond the framework of a separate municipality, it is obvious that some state structure should act as a customer. For most of the largest agglomerations in Russia, these are state authorities of the region, on the territory of which they are formed. Draft Federal Law "On Urban Agglomerations", in particular, assumes that they will coordinate the activities of executive authorities of subjects and local governments on the development of urban agglomerations; prepare proposals for defining goals, objectives and activities aimed at ensuring their sustainable development; to carry out measures of state support; coordinate drafts of comprehensive plans for the development of urban agglomerations [14]. Based on this set of functions, the legislative body of the subject and the regional administration are most consistent with this position in the draft. However, in the case of Krasnodar agglomeration, there is a problem associated with its location on the territory of both Krasnodar Krai and the Republic of Adygea. According to the aforementioned Draft Law, the specifics of the formation and management of the development of urban agglomerations in this case are established by an agreement between the relevant subjects of the Russian Federation. In this case, a commission for the development of an agglomeration can be created by decisions of two heads of constituent entities under their co-chairmanship with the inclusion of representatives of regional executive and legislative bodies, as well as heads of municipalities that form the agglomeration.

The target groups of the project are: the population of the municipalities that make up the agglomeration, business structures operating on its territory. It is advisable to assign the project management functions to the administration of the city of Krasnodar, which is the center of the agglomeration and a key link in the system of metropolitan administration. It is necessary to create a project group of representatives of municipalities included in the agglomeration, with the involvement of specialists from regional authorities, experts from the scientific community, business, and leaders of local communities.

The aim of the project is to create conditions for the systemic development of the agglomeration. For this, the following tasks must be solved:

- determination of the spatial boundaries of the agglomeration;

- creation of an agglomeration management system;

- correlation of the main aspects of its development with the tasks of national projects of the corresponding orientation;

- institutionalization of the agglomeration on the basis of the adoption of relevant regulations (signing of an inter-municipal agreement, etc.).

The main project risks include:

- the emergence of contradictions at the level of the constituent entities of the federation and at the inter-municipal level regarding the distribution of resources and benefits from its implementation;

- protests with an updated ethnic component (on the territory of the Republic of Adygea);

- deepening of the economic crisis, lack of resources for project implementation.

- The time period for the project is up to two years.

\section{CONCLUSION}

The relevance of the project approach to the management of urban agglomerations is associated with the possibility of implementing unique measures and building up resources for the formation of innovative technologies of management influences on the related subsystems of the urban agglomeration and the processes occurring in them. The formation and further development of Krasnodar agglomeration is integrated with the implementation of national and regional 
projects, as well as project activities at the municipal level.

The goal of the project for the development of Krasnodar urban agglomeration is to create conditions for the sustainable development of all its subsystems. The tasks of the project include delimitation of the boundaries of the agglomeration, creation of a management system, "linking" the development tasks of the main subsystems of the agglomeration to the tasks of national projects of the corresponding focus, institutionalization of the agglomeration on the basis of the adoption of appropriate regulatory acts.

The target groups of the project are: the population of the municipalities that make up the agglomeration, business structures operating on its territory. The project group will include representatives of municipalities that make up the agglomeration, as well as specialists from regional authorities, experts from the scientific community, business, and leaders of local communities. It is advisable to assign the project management functions to the administration of the city of Krasnodar, which is the center of the agglomeration and a key link in the system of metropolitan administration.

At the same time, it is necessary to take into account the possible risks of the project, which include the emergence of contradictions at the level of the constituent entities of the Federation and at the intermunicipal level regarding the distribution of resources and benefits from its implementation, the deepening of the economic crisis and the associated lack of resources for the implementation of the project.

\section{References}

[1] Weber, A. The theory of industrial location / translation from German by N. Morozova / Ed. and with a foreword by N.N. Baransky. M. - L.: Book, 1926.

[2] Hoover, E.M. Location of Economic Activity / E.M. Hoover, N.Y.: McGraw-Hill, 1948, 244 p

[3] Lappo, G.M. Urban agglomerations of the USSR - Russia: features of dynamics in the twentieth century. / G.M. Lappo // Russian Expert Review. 2007. No. 4-5 (22). p. 6.

[4] Skutin, V.A. Economic and geographical problems of settlement in the Sverdlovsk urban agglomeration: dis. ... Cand. geogr. Sciences / V.A. Skutin. - Sverdlovsk, 1974.

[5] Lola, A.M. Fundamentals of city studies and city theory (in the Russian interpretation) / A.M. Lola. - M.: KomKniga, 2005. 344 p.

[6] Kositsky, Ya. V. Architectural and planning principles of urban design (urban studies) / Ya.V. Kositsky. - M.: 1974.

[7] Polyan, P.M. The age-old evolution of urban agglomerations and the threat of degradation of the support frame for the settlement of Russia [Electronic resource] / P.M. Polyan // Official site of the International Assemblies of Capitals and Large Cities "MAG". URL: http://www.egorod.ru.
[8] Migranyan, A.A. Theoretical aspects of the formation of competitive clusters in the countries with transitional economy / A.A. Migranyan // VESTNIK KRSU. 2002. No. 3. P. 30-34.

[9] Gutnov, A.E. The evolution of urban planning. / A.E. Gutnov M.: Stroyizdat, 1984, 256 p.

[10] Bolshakov, A.G. Fundamentals of the theory of urban and district planning / A.G. Bolshakov. - Irkutsk: Publishing house of ISTU, 2004. $215 \mathrm{p}$

[11] The development of urban agglomerations: an analytical review. - Issue. 2. [Electronic resource] // Official site of JSC Russian Institute of Urban Planning and Investment Development "Giprogor". - - Access: http://www.enter.giprogor.ru/files/Development_of_urban_aggl omerations_Vol2.pdf.

[12] The Spatial Development Strategy of the Russian Federation for the period up to 2025 URL: https://www.economy.gov.ru/material/file/a3d075aa813dc01f98 1d9e7fcb97265f/130219_207-p.pdf

[13] Kolba A.I., Tereshina M.V. Problems of using political and administrative resources of public administration of urban agglomerations: current state of research // Central Russian Journal of Social Sciences. 2019. № 6. P. 15-36.

[14] Draft Federal Law "On urban agglomerations". URL: http://www.consultant.ru/cons/cgi/online.cgi?req=doc \&base $=\mathrm{P}$ RJ\&n=199079\#08913716073603659

[15] Rozhdestvenskaya I.A. Project approach in managing the development of urban agglomerations // Management sciences in the modern world, 2018. No. 1. Ch.1. P. 544-547.

[16] Osborne D., Gaebler T. Reinventing Government: How the Entrepreneurial Spirit Is Transforming the Public Sector. Reading, MA: Addison-Wesley, 1992.

[17] Polkovnikov A.V., Dubovik M.F. Project management Full MBA course. Moscow: Olimp-Biznes, 2015. 552. p.

[18] Volchkova I.V. Theory and practice of managing the development of agglomerations. Tomsk: Publishing house of TSUAB, 2014. P. 234

[19] Kolyasnikov, V.A. Development of the concept of "urban agglomeration" / A.V. Kolyasnikov // Academic Bulletin UralNIIproekt RAASN Yekaterinburg: UraNIIproekt. 2015. No. 2, P. 10-15.

[20] Projects. URL: https://национальныепроекты.pф/projects

[21] Yurieva T.V. Project approach as a tool for the implementation of strategic goals // Economic Sciences. 2014. No. 11 (120). P. 7-10. 